\title{
Antimicrobial Photodynamic Therapy: An Effective Alternative Approach to Control Bacterial Infections
}

\author{
Hassan Mahmoudi ${ }^{1}$, Abbas Bahador², Maryam Pourhajibagher ${ }^{3}$, Mohammad Yousef Alikhani ${ }^{*}$ \\ ${ }^{1}$ Microbiology Department, Hamadan University of Medical Sciences, Hamadan, Iran \\ ${ }^{2}$ Microbiology Department, Tehran University of Medical Sciences, Tehran, Iran \\ ${ }^{3}$ Dental Research Center, Dentistry Research Institute, Tehran University of Medical Sciences, Tehran, Iran
}

*Correspondence to

Mohammad Yousef Alikhani,

Department of Microbiology,

Hamadan University of Medical

Sciences, Hamadan, Iran.

Tel: +98-918-9539458,

Email: Alikhani43@yahoo.com

Published online 28 July 2018

\begin{abstract}
Introduction: The purpose of this review was to evaluate the available literature for in vitro and in vivo effectiveness of antimicrobial Photodynamic therapy (aPDT) in the field of bacteriology. Methods: A review of the relevant articles carried out in PubMed and Scopus to determine the efficiency of aPDT used in the reduction of microbial infection. Thirty-one relevant documents retrieved from PubMed, Scopus by inserting "antimicrobial photodynamic therapy" and "bacterial infection" and "photodynamic therapy" keywords.

Results: According to different results, aPDT can be used as an adjuvant for the treatment of infectious diseases. The use of photosensitizer methylene blue, toluidine blue $\mathrm{O}$ (TBO), indocyanine green with light diode laser centered at $(630 \pm 10 \mathrm{~nm})$ and $(650 \pm 10 \mathrm{~nm})$ wavelengths have been shown to have significant results for the treatment of infectious diseases and bactericidal properties

Conclusion: These findings suggest that, aPDT can be an efficient method in the treatment of localized and superficial infections.

Keywords: Antimicrobial photodynamic therapy; Photosensitizer; Skin infections.
\end{abstract}

\section{Introduction}

Thebroad antibiotic resistance of hospital pathogens, inducing thigh index of human morbidity andmortality, as well as hospital costs. ${ }^{1}$ The developed antibiotic resistant strains of bacteria to antibiotic therapy imply the demand for alternative treatments for infectious disease. One strategy that may lead to improved antimicrobial treatment is the application of antimicrobial photodynamic therapy (aPDT). ${ }^{2}$ aPDT involves the use of a chemical photosensitizer or a nontoxic photoactivatable dye, visible light, and reactive oxygen. The therapy is based on the energy (absorbed as light via the intracellular photosensitizer) transferred to the oxygen molecules producing extremely reactive mediation, such as singlet oxygen and superoxide, that are noxious to the cells. ${ }^{3,4}$

History of Photodynamic Therapy

The origin of the light therapy found as an alternative treatment in medical profession and surgery from ancient to contemporary time. Phototherapy trace its root back to ancient Greece, Egypt and India, however not applied for centuries. Ultimately, it has been unearthed via the westerly society at the outset of the 20th century by a Danish physicist, Niels Finsen. He succeeded to prove the usage of photodynamic therapy by applying heat and light filtered through a carbon lamp for the treatment of cutaneous tubercles known as lupus vulgaris. ${ }^{5}$ The idea of necrobiosis caused by action and reaction between light and chemicals were the earliest described by Raab in Munich. He found that chemical changes in the presence of a pigment called acridine light, inducing the death of a paramecium. ${ }^{6}$ The next work that was done in the laboratory by Von Tappeiner, coined the term "Photodynamic action" was revealed that oxygen is essential for this operation. The next few years Thomas Dougherty et al at the Roswell Park Cancer Institute in clinical examined PDT. Photodynamic therapy was confirmed by the Food and Drug Administration in 1999 to treat pre-cancerous skin lesions in the head and face. ${ }^{7}$

The Mechanism of Action of Photodynamic Therapy PDT comprise the application of visible light, combined with a photosensitizer (PS) and with the oxygen (Figure 1). ${ }^{8}$ PDT is based on the interplay of visible light and a photosensitizer agent which under photo-activation generate short lived cytotoxic species in site. After stimulation, the photosensitizer is converted from singlet to triplet state by an intersystem crossing process which, in turn, reacts with surrounding molecules to produce radical species and hydrogen peroxide, or transfers its

Please cite this article as follows: Mahmoudi $\mathrm{H}$, Bahador A, Pourhajibagher M, Alikhani MY. Antimicrobial photodynamic therapy: an effective alternative approach to control bacterial infections. J Lasers Med Sci. 2018;9(3):154-160. doi:10.15171/jlms.2018.29. 
energy to molecular oxygen to manufacture singlet oxygen. Oxygen species that are capable of eliminating target cells by oxidative stress to cell membranes and other cellular parts. ${ }^{9}$

\section{Photosensitizers}

An optimally photosensitizers ought to have favorable structural features including physical, chemical, and biological. Many optical photosensitizers for photodynamic therapy have been tested in vitro as well as in vivo conditions. Optimal photosensitizers for aPDT of porphyrins derivatives, chlorine and phthalocyanine are porphycenes and phenothiazines' colors such as toluidine blue $\mathrm{O}$ (TBO), methylene blue (MB) and Azure is applied. Optimal photosensitizers' cationic tetrapyrrole contain quaternary groups based on foundations such as porphyrin and phthalocyanine, and spherical C60 molecules are produced. The mechanism of all optimal photosensitizers operation or polymer photosensitizers conjugate to light absorption or self-promoted uptake pathway, respectively.

In this process, at first the cationic molecules, $\mathrm{Mg}^{+2}$ and $\mathrm{Ca}^{+2}$ are displaced in outer membrane, and then followed by the light photosensitizer absorption via permeability of outer membrane, and finally of the cell membrane is destructed Table $1 .{ }^{10-12}$

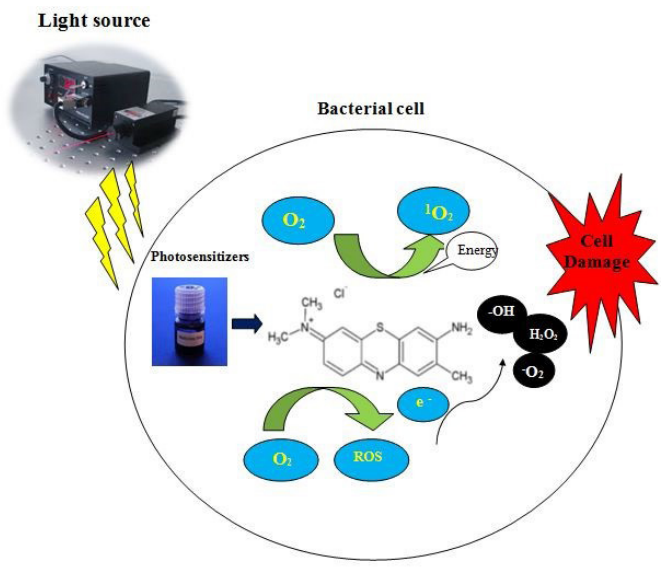

Figure 1. The Mchanism of Antibacterial Photodynamic Therapy. Photosensitizers can be preferentially uptaken by bacteria, accumulating inside the bacteria and in the cytoplasm membranes, or in the proximity. The photosensitizer in its ground singlet state is exposed to light of a appropriate wavelength and attract a photon. Then, the photosensitizer transferral energy from light to molecular oxygen to produce singlet oxygen and free radicals that are cytotoxic to cells.

Light Sources Used in Photodynamic Therapy

Photodynamic therapy requires a light source for triggering the photosensitizer exposures with a low power visible light at a particular wavelength. More the optical

Table 1. Photosensitizers Used in Antimicrobial Photodynamic Therapy

\begin{tabular}{|c|c|c|}
\hline Photosensitizer & Chemical Structure & Referance \\
\hline Methylene blue & & $(4,13)$ \\
\hline Toluidine blue & & $(4,13)$ \\
\hline Indocyanine Green & & (14) \\
\hline Curcumin & & (15) \\
\hline Rose bengal & & $(4,13)$ \\
\hline Chlorin(e6) & & (16) \\
\hline
\end{tabular}


photosensitizers are actuated by red light in $630 \mathrm{~nm}$ and $700 \mathrm{~nm}$ wavelengths. Corresponding to a light influence depth of $0.5 \mathrm{~cm}$ to $1.5 .17,18$

\section{Methods}

A review of pertinent literatures was carried out in PubMed and Scopus to determine the efficiency of aPDT applied in the reduction of microbial infection. Sixty relevant documents were retrieved from PubMed, Scopus by inserting "Antimicrobial photodynamic therapy" and "Bacterial infection" and "photodynamic therapy" keywords.

\section{Results}

Application of Photodynamic Therapy In Vitro

For this review, the summary of the selected studies, the authors' name, the general description of the studies, and the results are presented. The effect of photodynamic inactivation in 14 clinical strains Staphylococcus aureus resistant to methicillin (MSRA) and 26 clinical strains Staphylococcus aureus susceptible to methicillin (MSSA) were evaluated by Kashef et al. The results showed that the toluidine blue- and MB photodynamic inactivation on MRSA strains to reduce ranging from 1-1.3 $\log _{10}-0.7-1$ $\log _{10} \mathrm{CFU} / \mathrm{mL}$, respectively. In the case of MSSA strains the achieved results for toluidine blue- and $\mathrm{MB}$ photodynamic inactivation included viable count reduction ranging approximately from 1.1 to $1.3 \log _{10}-$ 0.7- $0.9 \log _{10} \mathrm{CFU} / \mathrm{mL}$, respectively. ${ }^{19}$ In another study, Maisch et al investigated the impact of photodynamic therapy with photosensitizers (XF73, XF70,CTP1) on strains of $S$. aureus resistant to methicillin. The findings showed that concentrations $(0.005 \mu \mathrm{M})$ of photosensitizers, using light $\left(13.7 \mathrm{~J} / \mathrm{cm}^{2}\right)$ for 10 minutes to reduce a $3 \log _{10}$ (>99.9\%) of bacteria. ${ }^{20}$ Grinholc et al evaluated the bactericidal effects of the photodynamic inactivation with a porphoporphyrin photosensitizer at $624 \mathrm{~nm}$ wavelength with an energy density of $\left(0.2 \mathrm{~J} / \mathrm{cm}^{2}\right)$ on 40 clinical isolates of methicillin-resistant $S$. aureus and 40 clinical isolates of methicillin-sensitive $S$. aureus isolated patients admitted to the hospital in Gdansk. The results of the study indicated the reduction of $3 \log _{10}$ in the number of bacteria. $^{21}$ the effect of aPDT with Radachlorin photosensitizer on S. aureus was studied by Fekrazad et al. The findings showed that the number of viable $S$. aureus was decreased to $6.28 \log _{10}$ in a study group that was used for photosensitizers with laser light. ${ }^{22}$ Kashef et al studied the photodynamic inactivation influence on Escherichia coli (ATCC25922) and clinical resistant strains of E. coli using photosensitizers of $\mathrm{MB}$ and toluidine blue $\mathrm{O}$ (TBO). $\mathrm{MB}(50 \mu \mathrm{g} / \mathrm{mL})$ with a laser light of red $\left(163.8 \mathrm{~J} / \mathrm{cm}^{2}\right)$ capable of reducing $53.1 \%$ and $37.6 \%$ in the number of viable E. coli (ATCC25922) and drug resistant E. coli (the initial number of bacteria was $10^{4}-10^{5} \mathrm{Cfu} / \mathrm{mL}$ ). Moreover, TBO $(50 \mu \mathrm{g} / \mathrm{mL})$ and a laser dose of $46.68 \mathrm{~J} / \mathrm{cm}^{2} \mathrm{killed}$ $98.2 \%$ and $83.2 \%$ of E. coli (ATCC25922) and drug- resistant E. coli. ${ }^{23}$ In another study, Ragas et al studied the photodynamic efficiency on the plankton condition in $A$. baumannii. The results showed that the decreasing in the number of $A$. baumannii in plankton condition was $2-3 \log _{10}$ reported after photodynamic inactivation with 2 photosensitizers of TBO and MB. ${ }^{24}$ Kashef et al assessed the efficacy of photodynamic therapy on A. baumannii. The findings of the study showed the reducing in logarithmic growth of live cells after photodynamic inactivation with $\mathrm{MB}$ and $\mathrm{TBO}$ (TBO) for 5 strains of Acinetobacter baumannii was between $\left(1.3 \log _{10}\right)$, (3.5$\left.2.4 \log _{10}\right), \quad\left(2.9-2.2 \log _{10}\right)$ and $\left(2.6 \log _{10}\right)$. Furthermore, photodynamic inactivation reduced the minimum inhibitory concentrations of growth inhibitors into Azithromycin, Imipenem, Ciprofloxacin and Gentamicin antibiotics. ${ }^{25}$ Donnelly et al performed a photodynamic test of 2 photosensitizers of TBO and meso-Tetra(Nmethyl-4-pyridyl) porphine tetra tosylate (TMP) at a concentration of $5 \mathrm{mg} / \mathrm{mL}$ on 5 strains of Pseudomonas aeruginosa isolated from cystic fibrosis, and the laser light killed $99.99 \%$ of bacteria. ${ }^{26}$ Garcia et al investigated the effect of photodynamic therapy using a Hypericin sensitizer against biofilms formed of methicillin-resistant and sensitive staphylococci. The results of this study showed planktonic forms destruction in 10 minutes exposed to laser light. ${ }^{27}$ The study by Miyabe et al evaluated the impact of photodynamic therapy using photosensitizers $\mathrm{MB}(3 \mathrm{mM})$ and gallium-aluminium lasers at a wavelength of $660 \mathrm{~nm}$ red light with an energy density and time of $35 \mathrm{~mW}, 10 \mathrm{~J}$, and 285 seconds, on $S$. aureus. The findings showed the number of bacteria (4.89-6.83 $\log _{10} \mathrm{CFU} / \mathrm{mL}$ ) decreased in relation to the initial concentration of bacteria. ${ }^{28}$ Grinholc et al investigated the effect of photodynamic therapy using a protoporphyrin $25 \mu \mathrm{M}$ photosensitizer with laser radiation at a wavelength of $624 \mathrm{~nm}$ on the methicillinresistant (MRSA) and sensitive strains (MSSA) of $S$. aureus. The results of this study indicated that there was a reduction of $0-3 \log _{10}$ and $0.2-3 \log _{10}$ strains of MRSA and MSSA in the number of bacteria, respectively. ${ }^{21}$ Sharma et al assessed the effectiveness of aPDT on S. aureus biofilm formation. In this study, a TBO photosensitizer was used at concentrations of $10-80 \mu \mathrm{m}$ and light source diode laser with a $640 \mathrm{~nm}$ wavelength. The results showed that at 40 $\mu \mathrm{M}$ concentration, biofilm was destroyed and has the least cytotoxic effect in cells. ${ }^{29} \mathrm{Li}$ et al investigated the effect of photodynamic therapy with 5-aminolevulinic acid (ALA) photosensitizer and a concentration of $40 \mathrm{mM}$ and an optical source laser with $635 \mathrm{~nm}$ wavelength for activating ALA at doses $\left(0,100,200,300 \mathrm{~J} / \mathrm{cm}^{2}\right)$ used. The results of this study showed that ALA without exposure to light or red light does not affect bacterial biofilm. However, a significant number of cells in the biofilm was inactivated during radiation with different doses of red light in the presence of 5-aminolevulinic acid, and at the dosage of $300 \mathrm{~J} / \mathrm{cm}^{2}$, all bacteria (99.99\%) were killed. ${ }^{30}$ 
Khalil et al reported the effect of laser light on MRSA strains using TBO photosensitizer at a concentration of $50 \mu \mathrm{g} / \mathrm{mL}$ and a HeNe laser light with a wavelength of $632.8 \mathrm{~nm}$ in $1,5,10$ minutes. The findings of the study indicated that $100 \%$ of the bacteria were killed in 15 minutes. Antibiotic resistance patterns of these strains were different before and after laser radiation, so that they were resistant to gentamicin $10 \mu \mathrm{g}$ prior to the laser irradiation, and had an intermediate resistance to vancomycin. Moreover, after laser radiation, they became sensitive to these antibiotics. ${ }^{31}$ Tang et al showed the effect of photodynamic therapy on clinical isolates of MRSA strains and S. aureus strain ATCC 25923 under the conditions of using $\mathrm{TBO}$ photosensitizer at concentrations $(80 \mu \mathrm{M}-400 \mu \mathrm{M})$ and Pl-ce6 at a concentration of $(8 \mu \mathrm{M})$ and an optical source of laser $600 \mathrm{~nm}$ wavelength with doses $\left(10-30 \mathrm{~J} / \mathrm{cm}^{2}\right)$ for 30 minutes. The results of this study showed that $\mathrm{Pl}-\mathrm{ce} 6$ and $\mathrm{TBO}$ at the concentration $(8$ $\mu \mathrm{M}, 30 \mathrm{~J} / \mathrm{cm}^{2}-80 \mu \mathrm{M}, 30 \mathrm{~J} / \mathrm{cm}^{2}$ ) induced killing of MRSA $\left(4 \log _{10}\right.$ and $\left.3 \log _{10}\right)$ and S. aureus (ATCC $25923\left(3 \log _{10}{ }^{-}\right.$ $\left.\left.2 \log _{10}\right)\right) .{ }^{32}$ Pourhajibagher et al determined the efficacy of sub-lethal photodynamic therapy with the ability to form biofilm and the metabolic activity of Enterococcus faecal under in vitro conditions by using indocyanine green photosensitizer at concentrations $(2 \mathrm{mg} / \mathrm{mL})$ and TBO and $\mathrm{MB}$ at a concentration of $0.2 \mathrm{mg} / \mathrm{mL}$ with a diode laser as light source for $\mathrm{TBO}$ and $\mathrm{MB}$ and indocyanine green were $635 \mathrm{~nm}-200 \mathrm{~mW}, 660 \mathrm{~nm}-150 \mathrm{~mW}, 810 \mathrm{~nm}$ $200 \mathrm{~mW}$, respectively. The findings showed that PDT-ICG and PDT-MB and TBO-PDT sub-lethal reduces $42.8 \%$, $22.6 \%$, and $19.5 \%$ of biofilms, the sub-lethal dose of PDTICG and PDT-MB and TBO PDT reduced 98\%, 94\%, 82\% of metabolic activity, in Enterococcus faecal, respectively. ${ }^{33}$ In another study, Pourhajibagher et al investigated the effect of sub-lethal photodynamic therapy on Porphyromongus gingivalis isolated from endodontic infections using diode laser light. The findings of this study showed that MB-sPAD $\left(25 \mu \mathrm{g} / \mathrm{ml}-117.18 \mathrm{~J} / \mathrm{cm}^{2}\right)$ and $\left(50-100 \mu \mathrm{g} / \mathrm{mL}-117.18 \mathrm{~J} / \mathrm{cm}^{2}\right)$ significantly inhibited the growth of $P$. gingivalis than the control group. ${ }^{34}$ Boluki et al studied the effect of photodynamic therapy (TBO with $630 \mathrm{~nm}$ LED laser light) with colistin on A. baumannii pandrug resistant strains. The results of this study showed that the effect of TBO+LED significantly reduced the growth of bacterium. Although after calculating sublethal effects, the expressions of Pmr A-Pmr B genes were evaluated through real-time PCR method, it was indicated that rates were reduced in 6.1 to 4.1 fold. ${ }^{35}$ The efficacy of photodynamic therapy on the formation of biofilm $P$. gingivalis was evaluated by Pourhajibagher et al using the inducianin green photosensitizer. The results showed that indosanine green at a concentration of $62.5-1000 \mu \mathrm{g} / \mathrm{mL}$ reduced a significant number of bacteria, which decreased compared to the control group (23.2\%-93.7\%). ${ }^{36}$ Soukos et al investigated the effect of photodynamic therapy on $E$. faecalis in biofilm formed at root infections under the laboratory conditions. The findings of the study suggest that $97 \%$ of the bacteria were reduced when they were exposed to red laser light and $\mathrm{MB}$ at a concentration of $(25 \mathrm{mg} / \mathrm{mL}) \cdot{ }^{37}$

Application of Photodynamic Therapy In Vivo Maisch et al investigated the intrusive and antibacterial effects of XF 73 (porphyrin cationic photosensitizer) on $S$. aureus (MRSA) in the pig's skin. They applied 2 methods for conducting the study. In the first method, they placed the bacterium in a XF73 solution, and then placed it on the pig's skin. In the second method, they placed the bacterium on the pig's skin, then placed the XF73 on the pig's skin for just 1 hour of dressing. Photoinactivation in the first method led to a $3-\log _{10}$ reduction in S. aureus, while in the second method $S$. aureus reduced by $1-\log _{10}{ }^{38}$ Orenstein et al used a mixture of deuteroporphyrinhemin, and successfully disinfected burns infected with S. aureus. ${ }^{39}$ Fonseca et al contaminated single-root teeth with E. faecalis and incubated them for 48 hours at $35^{\circ} \mathrm{C}$. Then the teeth placed in a TBO solution $(0.0125 \%)$ for 5 minutes and for photodynamic therapy used $660 \mathrm{~nm}$ and $50 \mathrm{~mW}$ light irradiation. The reduction in the number of CFUs in the treated group was about 99.9, while in untreated group there was an increase of $2.6 \% .^{40}$ SivieriAraujo et al in a survey examined the effectiveness of antimicrobial photodynamic upon tissue responses and cytokine production using a curcumin photosensitizer agent. The study process was conducted in which saline polyethylene tubes were introduced as control samples and sodium hypochlorite 5\% and aPDT containing 500 $\mathrm{mg} / \mathrm{mL}$ curcumin photosensitizer was put in the back of the connective tissue of the wistar rats. Seven, 15, 30, 60 and 90 days after planting, animals were exterminated and the tubes were removed with surrounding tissue. The results of the study indicated that the tissues reacted at days 7. Antimicrobial photodynamics increased the amount of IL-1B at all times $(P<0.05)$. IL-6 levels were highest at a 90 -day period with aPDT. ${ }^{41}$ Jung et al investigated the effect of PDT on Hemophilus influenza in vivo, and Streptococcus pneumoniae in Meriones unguiculatus rats. Twenty microliters of the bacterial solution $\left(10^{6} \mathrm{CFU}\right)$ injected into the bullae under sterile conditions. PDT was performed 2 days after infection by injection of $20 \mu \mathrm{L}$ a Hematoporphyring $(1 \mathrm{mg} / \mathrm{mL})$ derivative photogeram inside the bulla and exposure to a $632 \mathrm{~nm}$ laser light with $90 \mathrm{~J}$ power. PDT was effective in eliminating $S$. pneumonia in $87 \%$, whereas it was effective in killing of $H$. influenza in $50 \%$ of the infected bullae with otitis media with effusion. ${ }^{42}$ In a preliminary clinical trial, 13 patients orally administered $20 \mathrm{mg} / \mathrm{kg} 5$-aminolevulinic, and 45 minutes later, the antrum area of the stomach was irradiated by an endoscope with blue laser $\left(50 \mathrm{~J} / \mathrm{cm}^{2}-405 \mathrm{~nm}\right)$. Their results showed that in the samples that were exposed to radiation, the amount of $H$. pylori was lower, compared to the control areas. ${ }^{43}$ Geralde et al using PDT treated 
pneumonia caused by $S$. pneumoniae. Their hairless mice with S. pneumoniae were infected. After 2 days with antimicrobial photodynamics, infected mice were treated. In the control group, between $10^{3}-10^{4} \mathrm{CFU} / \mathrm{mL}$ of bacteria in mice was grown. However, in the treatment group with antimicrobial photodynamic, bacteria did not grow in $80 \%$ of the infected animals. Based on the results, the animals after 50 days were re-examined. In the PDT group, no death was observed, but in the control group, $60 \%$ of the infected mice were died. ${ }^{1}$ Ahangari et al compared the effects of antibacterial calcium hydroxide and photodynamic therapy on E. faecalis in teeth with periapical lesions under in vivo conditions. This study was performed on 20 patients, and did not succeed in treating endodontic. In this study, group $1(n=10)$ was treated with antimicrobial photodynamic (880 $\mathrm{nm}$ diode laser with 50 $\mathrm{mg} / \mathrm{mL} \mathrm{MB}$ ), while calcium hydroxide was used in group 2 for 1 week. Control samples were taken with sterile paper points and rotary F3 pro taper. The findings of this survey showed that the number of bacteria were declined in both groups after intervention $(P<0.001)$. However, there was no important difference in the number of colonies among the two groups. ${ }^{44}$ The study by Wu et al evaluated the effect of photodynamic therapy via using chlorin e6 against $P$. aeruginosa keratitis in mice under in vivo conditions. With the scratch on the mouse corneal epithelial tissue, the mouse corneal was infected with $P$. aeruginosa (strain PA54). After 24 hours, the chlorine (e6) at concentration $0 \%$ (control group), $0.01 \%, 0.05 \%, 0.1 \%$ with red light compound (PDI) were used. After 2 days, the eyes of the mice were picked up for counting the bacteria. The results showed that the number of bacteria in the group treated with PDI significantly decreased..$^{45}$ de Almeida et al investigated the therapeutic impact of photodynamic therapy in none diabetic $(n=120)$ and diabetic $(n=120)$ rats with the experimental periodontal disease. Then, infected rats were divided into saline washing groups with saline solution, washing with TBO, laser radiation (660 $\mathrm{nm}, 24 \mathrm{~J}$ ) and PDT (toluiden blue + laser radiation). After that, 10 animals from the experimental groups and the subgroups were evaluated in days 7, 15 and 30 . The results of this study showed that less bone loss $\left(0.33 \pm 0.05 \mathrm{~mm}^{2}\right.$, $\left.0.35 \pm 0.06 \mathrm{~mm}^{2}, 0.27 \pm 0.07 \mathrm{~mm}^{2}\right)$ and SRP $(1.11 \pm 0.11$ $\left.\mathrm{mm}^{2}, 0.84 \pm 0.12 \mathrm{~mm}^{2}, 0.97 \pm 0.13 \mathrm{~mm}^{2}\right)$ was observed in days 7,15 , and 30 , respectively $(P<0.05)$. In the TBO group bone loss was $\left(0.51 \pm 0.12 \mathrm{~mm}^{2}, 0.70 \pm 0.13 \mathrm{~mm}^{2}\right.$, $\left.0.64 \pm 0.08 \mathrm{~mm}^{2}\right)$ in days 7,15 and 30 , respectively. In the laser group bone loss was $\left(0.59 \pm 0.03 \mathrm{~mm}^{2}, 0.61 \pm 0.04\right.$ $\mathrm{mm}^{2}, 0.61 \pm 0.03 \mathrm{~mm}^{2}$ ) in days 7,15 , and 30 of evaluation. Finally, the group D, which was treated with PDT, showed less bone loss $\left(0.27 \pm 0.06 \mathrm{~mm}^{2}, 0.24 \pm 0.02 \mathrm{~mm}^{2}, 0.29 \pm\right.$ $0.03 \mathrm{~mm}^{2}$ ) in days 7, 15 and 30, respectively. Therefore it was much less than other groups. Findings of this study confirmed that, PDT can be utilized as a supplementary to periodontal treatment. ${ }^{46}$

\section{Conclusion}

The data obtained of this study demonstrated that bacteria were susceptible to photosensitizer (MB, $\mathrm{TBO}$, indocyanine green) in the presence of light diode laser. This review suggests that the PDT may useful for treatment of infection diseases. PDT is a technique that has been shown to be effective in vivo and invitro against pathogen bacteria. Doubtless, aPDT has noticeable in the nearby prospect not only for the treatment of infections, but also in non-clinical utilization in different fields.

\section{Ethical Considerations}

This report does not include any investigations with human participants or animals conducted by any of the authors.

\section{Funding}

No funding was obtained.

\section{Conflict of Interests}

The authors declare that they have no conflicts of interest.

\section{References}

1. Geralde MC, Leite IS, Inada NM, et al. Pneumonia treatment by photodynamic therapy with extracorporeal illumination - an experimental model. Physiol Rep. 2017;5(5). doi:10.14814/phy2.13190

2. Nakonechny F, Firer MA, Nitzan Y, Nisnevitch M. Intracellular antimicrobial photodynamic therapy: a novel technique for efficient eradication of pathogenic bacteria. Photochem Photobiol. 2010;86(6):1350-1355. doi:10.1111/ j.1751-1097.2010.00804.x

3. Shackley DC, Whitehurst C, Clarke NW, Betts C, Moore JV. Photodynamic therapy. J R Soc Med. 1999;92(11):562-565.

4. Tegos GP, Hamblin MR. Phenothiazinium antimicrobial photosensitizers are substrates of bacterial multidrug resistance pumps. Antimicrob Agents Chemother. 2006;50(1):196-203. doi:10.1128/aac.50.1.196-203.2006

5. Daniell MD, Hill JS. A history of photodynamic therapy. Aust N Z J Surg. 1991;61(5):340-348.

6. Raab $O$. On the effect of fluorescent substances on infusoria. $Z$ Biol. 1900;39:524-6.

7. Lui $H$, Anderson RR. Photodynamic therapy in dermatology. Shedding a different light on skin disease. Arch Dermatol. 1992;128(12):1631-1636.

8. St Denis TG, Hamblin MR. An introduction to photoantimicrobials: photodynamic therapy as a novel method of microbial pathogen eradication. In: Méndez-Vilas A, ed. Science against microbial pathogens: communicating current research and technological advances. 2011:675-683.

9. Darabpour E, Kashef N, Mashayekhan S. Chitosan nanoparticles enhance the efficiency of methylene bluemediated antimicrobial photodynamic inactivation of bacterial biofilms: An in vitro study. Photodiagnosis Photodyn Ther. 2016;14:211-217. doi:10.1016/j. pdpdt.2016.04.009

10. Rajesh S, Koshi E, Philip K, Mohan A. Antimicrobial photodynamic therapy: an overview. J Indian Soc 
Periodontol. 2011;15(4):323-327. doi:10.4103/0972$124 x .92563$

11. Malik R, Manocha A, Suresh DK. Photodynamic therapy-a strategic review. Indian J Dent Res. 2010;21(2):285-291. doi:10.4103/0970-9290.66659

12. Tegos GP, Anbe M, Yang C, et al. Protease-stable polycationic photosensitizer conjugates between polyethyleneimine and chlorin(e6) for broad-spectrum antimicrobial photoinactivation. Antimicrob Agents Chemother. 2006;50(4):1402-1410. doi:10.1128/ aac.50.4.1402-1410.2006

13. Cieplik F, Tabenski L, Buchalla W, Maisch T. Antimicrobial photodynamic therapy for inactivation of biofilms formed by oral key pathogens. Front Microbiol. 2014;5:405. doi:10.3389/fmicb.2014.00405

14. Wang XH, Peng HS, Yang W, Ren ZD, Liu XM, Liu YA. Indocyanine green-platinum porphyrins integrated conjugated polymer hybrid nanoparticles for nearinfrared-triggered photothermal and two-photon photodynamic therapy. J Mater Chem B. 2017;5(9):18561862. doi:10.1039/C6TB03215J

15. Ormond AB, Freeman HS. Dye Sensitizers for Photodynamic Therapy. Materials (Basel). 2013;6(3):817840. doi:10.3390/ma6030817

16. Embleton ML, Nair SP, Cookson BD, Wilson M. Selective lethal photosensitization of methicillin-resistant Staphylococcus aureus using an IgG-tin (IV) chlorin e6 conjugate. J Antimicrob Chemother. 2002;50(6):857-864.

17. Salva KA. Photodynamic therapy: unapproved uses, dosages, or indications. Clin Dermatol. 2002;20(5):571-581.

18. Grant WE, Speight PM, Hopper C, Bown SG. Photodynamic therapy: an effective, but non-selective treatment for superficial cancers of the oral cavity. Int $J$ Cancer. 1997;71(6):937-942.

19. Kashef N, Akbarizare M, Kamrava SK. Effect of sub-lethal photodynamic inactivation on the antibiotic susceptibility and biofilm formation of clinical Staphylococcus aureus isolates. Photodiagnosis Photodyn Ther. 2013;10(4):368373. doi:10.1016/j.pdpdt.2013.02.005

20. Maisch T, Bosl C, Szeimies RM, Lehn N, Abels C. Photodynamic effects of novel XF porphyrin derivatives on prokaryotic and eukaryotic cells. Antimicrob Agents Chemother. 2005;49(4):1542-1552. doi:10.1128/ aac.49.4.1542-1552.2005

21. Grinholc M, Szramka B, Kurlenda J, Graczyk A, Bielawski KP. Bactericidal effect of photodynamic inactivation against methicillin-resistant and methicillinsusceptible Staphylococcus aureus is strain-dependent. J Photochem Photobiol B. 2008;90(1):57-63. doi:10.1016/j. jphotobiol.2007.11.002

22. Fekrazad R, Zare H, Mohammadi Sepahvand S, Morsali $\mathrm{P}$. The effect of antimicrobial photodynamic therapy with radachlorin(R) on Staphylococcus aureus and Escherichia coli: an in vitro study. J Lasers Med Sci. 2014;5(2):82-85.

23. Kashef N, Ravaei Sharif Abadi G, Djavid GE. Phototoxicity of phenothiazinium dyes against methicillin-resistant Staphylococcus aureus and multi-drug resistant Escherichia coli. Photodiagnosis Photodyn Ther. 2012;9(1):11-15. doi:10.1016/j.pdpdt.2011.11.004

24. Ragas X, Dai T, Tegos GP, Agut M, Nonell S, Hamblin MR.
Photodynamic inactivation of Acinetobacter baumannii using phenothiazinium dyes: in vitro and in vivo studies. Lasers Surg Med. 2010;42(5):384-390. doi:10.1002/ $1 \mathrm{sm} .20922$

25. Kashef N, Yahyaei M. Photodynamic inactivation decreases the minimal inhibitory concentration of antibiotics against Acinetobacter baumannii from patients with respiratory tract infections. Laser in Medicine. 2014;11(3):13-18.

26. Donnelly RF, McCarron PA, Cassidy CM, Elborn JS, Tunney MM. Delivery of photosensitisers and light through mucus: investigations into the potential use of photodynamic therapy for treatment of Pseudomonas aeruginosa cystic fibrosis pulmonary infection. J Control Release. 2007;117(2):217-226. doi:10.1016/j.jconrel.2006.11.010

27. Garcia I, Ballesta S, Gilaberte Y, Rezusta A, Pascual A. Antimicrobial photodynamic activity of hypericin against methicillin-susceptible and resistant Staphylococcus aureus biofilms. Future Microbiol. 2015;10(3):347-356. doi: $10.2217 / \mathrm{fmb} .14 .114$

28. Miyabe M, Junqueira JC, Costa AC, Jorge AO, Ribeiro MS, Feist IS. Effect of photodynamic therapy on clinical isolates of Staphylococcus spp. Braz Oral Res. 2011;25(3):230-234.

29. Sharma M, Visai L, Bragheri F, Cristiani I, Gupta PK, Speziale P. Toluidine blue-mediated photodynamic effects on staphylococcal biofilms. Antimicrob Agents Chemother. 2008;52(1):299-305. doi:10.1128/aac.00988-07

30. Li X, Guo H, Tian Q, et al. Effects of 5-aminolevulinic acidmediated photodynamic therapy on antibiotic-resistant staphylococcal biofilm: an in vitro study. J Surg Res. 2013;184(2):1013-1021. doi:10.1016/j.jss.2013.03.094

31. Hajim KI, Salih DS, Rassam YZ. Laser light combined with a photosensitizer may eliminate methicillin-resistant strains of Staphylococcus aureus. Lasers Med Sci. 2010;25(5):743748. doi:10.1007/s10103-010-0803-Z

32. Tang HM, Hamblin MR, Yow CM. A comparative in vitro photoinactivation study of clinical isolates of multidrugresistant pathogens. J Infect Chemother. 2007;13(2):87-91. doi:10.1007/s10156-006-0501-8

33. Pourhajibagher M,Chiniforush N, ShahabiS, Ghorbanzadeh $\mathrm{R}$, Bahador A. Sub-lethal doses of photodynamic therapy affect biofilm formation ability and metabolic activity of Enterococcus faecalis. Photodiagnosis Photodyn Ther. 2016;15:159-166. doi:10.1016/j.pdpdt.2016.06.003

34. Pourhajibagher $\mathrm{M}$, Chiniforush $\mathrm{N}$, Raoofian $\mathrm{R}$, et al. Evaluation of photo-activated disinfection effectiveness with methylene blue against Porphyromonas gingivalis involved in endodontic infection: An in vitro study. Photodiagnosis Photodyn Ther. 2016;16:132-135. doi:10.1016/j.pdpdt.2016.09.008

35. Boluki E, Kazemian $\mathrm{H}$, Peeridogaheh $\mathrm{H}$, et al. Antimicrobial activity of photodynamic therapy in combination with colistin against a pan-drug resistant Acinetobacter baumannii isolated from burn patient. Photodiagnosis Photodyn Ther. 2017;18:1-5. doi:10.1016/j. pdpdt.2017.01.003

36. Pourhajibagher $M$, Chiniforush $N$, Ghorbanzadeh $\mathrm{R}$, Bahador A. Photo-activated disinfection based on indocyanine green against cell viability and biofilm formation of Porphyromonas gingivalis. Photodiagnosis Photodyn Ther. 2017;17:61-64. doi:10.1016/j. 
pdpdt.2016.10.003

37. Soukos NS, Ximenez-Fyvie LA, Hamblin MR, Socransky SS, Hasan T. Targeted antimicrobial photochemotherapy. Antimicrob Agents Chemother. 1998;42(10):2595-2601.

38. Maisch T, Bosl C, Szeimies RM, Love B, Abels C. Determination of the antibacterial efficacy of a new porphyrin-based photosensitizer against MRSA ex vivo. Photochem Photobiol Sci. 2007;6(5):545-551. doi:10.1039/ b614770d

39. Orenstein A, Klein D, Kopolovic J, et al. The use of porphyrins for eradication of Staphylococcus aureus in burn wound infections. FEMS Immunol Med Microbiol. 1997;19(4):307-314.

40. Fonseca MB, Junior PO, Pallota RC, et al. Photodynamic therapy for root canals infected with Enterococcus faecalis. Photomed Laser Surg. 2008;26(3):209-213. doi:10.1089/ pho.2007.2124

41. Sivieri-Araujo G, Queiroz IOA, Fabbro RD, et al. Rat tissue reaction and cytokine production induced by antimicrobial photodynamic therapy. Photodiagnosis Photodyn Ther. 2017;18:315-318. doi:10.1016/j.pdpdt.2017.04.002

42. Jung JY, Kwon PS, Ahn JC, Ge R, Suh MW, Rhee CK. In vitro and in vivo photodynamic therapy of otitis media in gerbils. Laryngoscope. 2009;119(9):1781-1787. doi:10.1002/ lary.20568

43. Wilder-Smith $\mathrm{CH}$, Wilder-Smith $\mathrm{P}$, Grosjean $\mathrm{P}$, et al. Photoeradication of Helicobacter pylori using 5-aminolevulinic acid: preliminary human studies. Lasers Surg Med. 2002;31(1):18-22. doi:10.1002/lsm.10066

44. Ahangari Z, Mojtahed Bidabadi M, Asnaashari M, Rahmati A, Tabatabaei FS. Comparison of the Antimicrobial Efficacy of Calcium Hydroxide and Photodynamic Therapy Against Enterococcus faecalis and Candida albicans in Teeth With Periapical Lesions; An In Vivo Study. J Lasers Med Sci. 2017;8(2):72-78. doi:10.15171/jlms.2017.13

45. Wu MF, Deichelbohrer M, Tschernig T, et al. Chlorin e6 mediated photodynamic inactivation for multidrug resistant Pseudomonas aeruginosa keratitis in mice in vivo. Sci Rep. 2017;7:44537. doi:10.1038/srep44537

46. de Almeida JM, Theodoro LH, Bosco AF, Nagata MJ, Bonfante S, Garcia VG. Treatment of experimental periodontal disease by photodynamic therapy in rats with diabetes. J Periodontol. 2008;79(11):2156-2165. doi:10.1902/jop.2008.080103 